\title{
Deconstructing Correctional Officer Deviance: Toward Typologies of Actions and Controls
}

Criminal Justice Review 38(I) $110-126$

(C) 2013 Georgia State University Reprints and permission: sagepub.com/journalsPermissions.nav DOI: I0.1 I77/07340|68|2473824 cjr.sagepub.com

@SAGE

\author{
Jeffrey lan Ross'
}

\begin{abstract}
This article reviews the scholarly research that has been conducted on the problem of correctional officer (CO) deviance. It then outlines the most dominant kinds of $\mathrm{CO}$ deviance and the solutions that have been proposed and, in part, implemented. In so doing, the author provides a typology of the categories of deviance and the variety of controls. The researcher concludes with several recommendations on how these findings might be utilized to further the research on this subject.
\end{abstract}

\section{Keywords}

correctional officers, deviance, ethics

\section{Introduction}

Although numerous definitions of deviance exist, at the very least, deviance is an action or behavior that violates generally accepted norms (Adler, 2005). Deviance is the foundation from which many of society's policies, practices, and laws are developed. Policies, practices, and laws are usually written because entities (from organizations to countries) codify certain acts of deviance. Deviance can and does occur in all workplaces and in all jobs, occupations, and professions.

Since the 1960s, numerous scholars have outlined various acts of deviance in certain jobs, occupations, and professions. From adolescent workers (Ruggerio, Greenberger, \& Steinberg, 1982) to doctors (Morrow, 1982), a steady stream of research and analysis of deviance has been published. Some of this work has examined deviance in the criminal justice professions. Unfortunately, the majority of this analysis has focused on the deviant actions of police officers (e.g., Barker \& Carter, 1994; Kappeler, Sluder, \& Alpert, 1998), and by comparison, little work has been done on correctional officers (COs). ${ }^{1}$

\footnotetext{
' School of Criminal Justice, College of Public Affairs, Center for Comparative and International Law, University of Baltimore, Baltimore, MD, USA

Corresponding Author:

Jeffrey lan Ross, School of Criminal Justice, College of Public Affairs, Center for Comparative and International Law, University of Baltimore, Baltimore, MD 2120I, USA.

Email: jross@ubalt.edu
} 
Thus, there has been a paucity of definitions of deviance (sometimes labeled misconduct) as applied to COs. More common are definitions of corruption. According to McCarthy (1996), corruption includes "the intentional violation of organizational norms (i.e., rules and regulations) by public employees for personal material gain" (p. 231). Such behavior would subsume theft, smuggling contraband, embezzlement of money from the correctional facility or inmates, theft of property, and misuse of authority (p. 232). Although a respectable start, this definition conflates deviance with corruption. Instead, perhaps a more generic definition would suffice. In the field of corrections, deviance is generally considered inappropriate work-related activities in which COs may engage. Although some COs commit acts of deviant behavior, rarely do introductory textbooks and scholarly articles on corrections tackle this subject at any great length. ${ }^{2}$ Authors and researchers might briefly mention violence or excessive force by $\mathrm{COs}$, but rarely do they conduct research or write anything about less visible deviant behaviors such as theft, corruption, or sexual assault.

Many correctional agencies and the American Correctional Association (ACA; the largest organization representing COs) have codes of ethics or standards of conduct - "dos" and "don'ts"which are taught to recruits and selectively reinforced by veterans and administrators of correctional organizations. Nonetheless, systematic analyses of compliance with and breaches of these standards are rarely attempted. A closely-related term to deviance is "corruption." Identifying and finding appropriate remedies to deviance can be difficult. Public officials (such as COs and administrators) may engage in morally reprehensible and/or ethically questionable behavior (e.g., accepting free meals from contractors), but it is hard to empirically determine when and how this conduct is sanctioned. This type of action may even occur with a supervisor's knowledge, an eventuality that calls into question if, in fact, norms are actually being violated.

When a news story describing an incident of alleged or real $\mathrm{CO}$ deviance is brought to the public's attention, an organization's legitimacy is typically challenged, and this can prompt some sort of official investigation. The controversial behavior will typically be compared to existing norms, policies, and practices, and one of the three things will commonly happen: the administration may publicly announce that it will no longer tolerate the controversial behavior; the administration might increase enforcement against rule breakers; or the rules and regulations will be changed to reflect current practices.

Responding to CO deviance becomes difficult in the cases in which nearly all of an organization's workers have violated an existing policy or practice over a considerable period of time and the supervisors and administrators have knowingly failed to take any meaningful remedial action. This is a situation in which a norm has not been violated, but a policy or practice has been.

As alluded to earlier, the discussion about deviance is intimately tied to the study of ethics. Clearly, COs face many temptations on the job, and deviant acts inevitably take place. The frequency of such occurrences, however, is generally a matter of speculation. Interest in deviant behavior has increased over the past decade, largely because of well-publicized inquiries that have occurred in the field of corrections and the allegations of abuse in connection with Baghdad's Abu Ghraib prison (Hersh, 2004). In fact, the National Commission on Safety and Abuse in Prisons (2005-2006; Gibbons \& Katzenbach, 2008) selected aspects of CO deviance as one of its major areas of investigation. Finally, because of the difficulty in obtaining reliable and comprehensive evidence, the extent of deviance perpetrated by COs is unknown, and no comparison of this type of deviance with that engaged in by law enforcement personnel, for example, or other professionals yet exists.

Given the lack of current scholarship in this area, this article briefly reviews the academic research which has been conducted on the problem of $\mathrm{CO}$ deviance. ${ }^{3}$ It then outlines the most dominant kinds of documented deviance and official/state-initiated solutions that have been proposed and, in many cases implemented. ${ }^{4}$ This information is organized into a typology that could be used for further analytical purposes. The author concludes with recommendations on how this article's 
findings could be utilized to better improve the field of corrections. ${ }^{5}$ Although some scholars of jails and prison have provided causal explanations of selected aspects of $\mathrm{CO}$ deviance (e.g., Worley \& Worley, 2013), no such attempt is made here.

\section{The Scholarly Literature on CO Deviance}

To date, some activist-produced publications (e.g., Human Rights Watch, 1996, 2001) and practitioner-based articles (e.g., Corrections Today) have reviewed selected aspects of CO deviance; however, a definitive body of scholarly literature about this behavior does not exist. Most typically, the studies concentrate on subcomponents of this phenomenon or related issues, such as $\mathrm{CO}$ power (e.g., Hepburn, 1985; Stichman, 2002; Stojkovic, 1984). Research focusing on the subcomponents of CO deviance has examined a variety of issues: racial and sexual discrimination and/or harassment (Britton, 1997; Camp, Saylor, \& Wright, 2001); CO corruption (McCarthy, 1996; Worley \& Cheesman, 2006); and excessive force and/or violence by COs (Bowker, 1980; Cohen, Cole, \& Bailey, 1976; Hemmens \& Atherton, 2000; Hemmens \& Stohr, 2001; Marquart, 1986). The topic of $\mathrm{CO}$ deviance is also embedded in complementary concepts, such as inmate boundary violations (Marquart, Barnhil, \& Balshaw-Biddle, 2001), and in larger issue studies that concentrate on professionalization as a solution to problems with COs (Farkas, 1990; Stinchcomb, 2000), selection procedures (Stinchcomb, 1988), and CO leadership (Stojkovic \& Farkas, 2003).

In broad terms, two major types of $\mathrm{CO}$ deviance exist: the abuse of power and corruption. The abuse of power is typically covered by studies of $\mathrm{CO}$ violence and of inmate victimization. Bowker (1980) produced what is considered by many scholars to be the most thorough treatment of CO deviant behavior. Though his research is outdated, he looked specifically at the victimization of prisoners by COs. Assessing the general handling of this subject matter, Bowker noted that "the treatment of the subject is superficial in that incidents tend to be mentioned only in passing (or as part of a polemical piece of writing), and they are not presented or analyzed in any great detail" (p. 143). He also pointed out that incidents of deviance "tend to be recorded factually" and not placed into a theoretical context:

[the] quality of the reporting of incidents is often difficult to determine. Reports are usually limited to the views of one of the participants or observers, with no corroboration from others. Even when reports are written by social scientists, they usually consist of second and third-person accounts derived from interviews rather than direct observation by the scientists. (p. 143)

Finally, Bowker (1980) challenged the variable definitions pertaining to victimization experiences. He organized victimization into three types: physical, psychological, and sexual. Although this perspective provides a foundational framework for research, the concept of deviance is more encompassing.

Corruption, which typically involves an attempt to achieve a personal economic gain, is given less attention in the scholarly writing on COs. One of the most important treatments of this subject, however, is Sykes's (1958) classic and controversial book The Society of Captives. In this publication, Sykes argued that most COs are, upon occasion, susceptible to corruption. He offers three major explanations for this behavior: correctional workers develop friendships with prisoners; they engage in reciprocity; and simply engage in "default" actions (e.g., COs may be either lazy or overcommitted, or they are unable or unwilling to spend the necessary time that is required to properly do their jobs). In its day, this book's conclusions were judged as relatively controversial, inspiring a number of research studies about COs' working conditions and relationships with inmates. During the 1960s and 1970s, some (e.g., Irwin, 1970; Irwin \& Cressy, 1962) questioned the efficacy of the functional model as portrayed by Sykes. In order to build upon this literature and place it into some 
sort of conceptual framework, the components of $\mathrm{CO}$ deviance and the possible solutions to the acts of misconduct are outlined. In addressing both issues, a typology that will have heuristic possibilities is advanced.

\section{Types of CO Deviance}

Based on multiple sources, ${ }^{6} 15$ primary types of deviance engaged in by correctional workers can be identified. This type of behavior includes but is not limited to: improper use of agency equipment and property; failure to fulfill the required duties of the job; mishandling/theft of inmate property; drinking alcohol on the job; accepting gifts from inmates and contractors; discrimination; abuse of authority; sexual relationships with inmates; smuggling contraband; theft; unnecessary violence against prisoners; general boundary violations; and sexual harassment of fellow COs. Most of these deviant behaviors are interrelated and self-explanatory, but the following section reviews each activity in detail. The processes can be further broken down into three categories depending on the target of the deviance (i.e., the institution, inmates, and fellow COs). Although in reality all three groups of behavior are interrelated, for clarity's sake, this outline will leave the categories separate.

\section{Deviance Against the Institution}

Improper Use/Misuse of Agency Equipment and Property. Multiple opportunities exist for COs and administrators to take advantage of their organizations' resources for personal benefit and/or use. This includes acts as simple as using photocopy machines (for birthday party invitations, recipes, school-related texts, etc); stealing office supplies and equipment (for a part-time business, home use, etc), and borrowing equipment such as vehicles when theirs is in the shop. At other times, because of boredom, anger, or frustration COs may break equipment, or they may use equipment against other COs as a practical joke (e.g., pepper spraying someone in the bathroom).

Using corrections equipment (or machines; e.g., walkie talkies, metal detectors, etc) in a manner in which it was not intended (including "monkey-wrenching" or purposely breaking equipment/ machines) is a frequent occurrence in factories and the industrial sector (Abbey, 1975). Many of these instances are acts of low scale, uncollectivized rebellion, a reflection of frustration with poorly functioning or maintained equipment/machines or of difficulties with the management of an institution. Additionally, if equipment/machines does not work properly, there may be a tendency among workers to further damage it, either as a demonstration of their discontent or as a means to compel the administrators to finally replace the faulty equipment/machines.

Purposely Shirking One's Duties. Periodically COs fail to perform their duties for other reasons than incompetence or a inability to remember. Such deliberate behavior could extend to: falsifying log entries when failing to do his or her rounds and/or when coming in late or leaving early; playing cards and/or computer games; using smart phones for personal business; watching television and/ or listening to the radio (e.g., during a sporting event broadcast); recreational reading; sleeping; leaving an assigned area without authorization; refusing to respond to prisoners and/or fellow officers requests because of general laziness; and taking longer breaks and lunch hours than given. In addition to ripping off the facility not giving it the value for ones labor, it can have the effect of creating compromised security and safety of other officers.

Theft of Correctional Facility Property. Institutional food is typically not only of poor quality, but some of it may also disappear even before being served in the mess hall. In some penitentiaries, staff may occasionally eat or steal the better food. They may take it home to feed their farm animals or their 
pets, or they may sell it to others. Additional items of value may also mysteriously disappear and make their way into the correctional workers' possession (Ross \& Richards, 2002, Chapter 12).

Abusing Sick Time. Although correctional employees are allowed to use sick time when they have a legitimate reason, as in many other institutions, reports of abuse of sick time periodically surface. Part of this deviance depends on the documentation personnel are required to submit to their supervisors, and the diligence of supervisors in reviewing this kind of behavior (Worley \& Worley, 2011).

Accepting Gifts From Inmates and Contractors. Occasionally, inmates (or their friends, families, and associates), because of camaraderie or in hopes of ensuring a future favor, try to give COs gifts. Likewise, contractors and suppliers to the facility or Department of Corrections (DOCs) may give COs gratuities or discounts on goods or services. The hope is that if their products or services are needed, these vendors will be favored. These gratuities are typically frowned upon by the senior administrators and accrediting bodies. Accepting gratuities may eventually (depending on the situation) lead to corruption and/or preferential treatment of inmates and contractors. This prevents the institution from dealing with the vendors they deal with in an unbiased fashion. Decisions regarding possible contracts may be made based on personal relationships rather than the contractor/vendor who can give the best quality service at a reasonable cost. And, during the lifetime of the contract, personal relationships may mitigate a CO complaining when there is poor service.

\section{Deviance Against Inmates}

Abuse of Authority. COs have a considerable amount of power while on the job (Clemmer, 1958). They can write up (submit negative reports about) inmates they do not like, or they can humiliate convicts in front of others. Other kinds of abuse include confiscating inmates possessions, destroying their belongings, playing with the thermostat settings, arbitrarily denying privileges, placing inmates who hate each other in the same cell, repeatedly tossing (searching) cells, repetitively strip-searching inmates, and frequently transferring inmates to different correctional facilities. Alternatively, COs can give some inmates housing that is more desirable or jobs, or more access to entertainment (e.g., television) and sports privileges. All combined, these kinds of actions are often referred to collectively as abuse of authority. "[This] frequently involves one, or all, of the following activities: the acceptance of inmate payoffs for special consideration in receiving legitimate prison privileges ... ; the acceptance of inmate payoffs for special consideration in obtaining or protecting illicit activities ... and extortion" (Freeman, 1999, p. 350).

Mishandling/Theft of Inmate Property. Inmates' possessions come in and out of the facility either when convicts are transferred to an institution or when friends and family mail or bring items to the prison. Inmates routinely complain that COs steal or damage their items. One recurring reason for this behavior is connected with the fact that, in the normal course of doing their jobs, officers must ensure the safety of the institution and prevent contraband from coming into the jail or prison. That is why, for example, COs are typically required to remove the covers of hardcover books and search inmates' personal effects at intake and during cell searches (Worley \& Cheeseman, 2006).

Discrimination Toward Inmates. The United States jail and prison system has experiencd a long history of discriminatory behavior directed toward certain racial, ethnic minority inmates (especially African American and Hispanics), those who are homosexual, lesbian, and transgender (Souryal, 2009). This can range from the kinds of amenities they are provided to being singled out for violence/excessive force. 
Violence/Excessive Force Against Prisoners. The prison staff can and do use violence against convicts. They are allowed by law to use force when life and property are in peril. Nonetheless, two major concerns arise from the use of force: How frequently is force used, and is it done in an indiscriminate manner? Most often, officers will avoid using violence if possible, since it creates ill will that the prisoners are not likely to forget. Instead, correctional workers rely on threats and humor to motivate inmates to comply with directives. When officers do beat inmates (not to be confused with excessive force), it is quite often because the latter have initiated or followed through on an attack or have instigated work strikes, riots, or escape attempts (Kerness \& Ehehosi, 2001; Pratt, Maahs, \& Hemmens, 1999).

Unlike the deadly violence that convicts inflict on one another, most acts of violence committed by COs are psychological. If the officers want to remind a prisoner about who is in charge, they might destroy that convict's mail, refuse to turn up the heat, deny telephone privileges, or toss the prisoner's cell more frequently than normal. In the middle of the night, while a convict is sleeping, COs may overturn a bed, dumping him or her onto the floor. COs do not usually take the time to politely wake-up an inmate; rather, the officers might drag him to the floor, handcuff him, and rummage through his personal items to search for weapons, drugs, or other contraband items. An officer who wants to particularly anger an inmate might confiscate pictures of loved ones, sheets, clothing, food, and legal papers.

Strip searches, ostensibly used to detect drugs and weapons, are another form of intimidation and violence. COs can order an arrestee to go through this humiliating act numerous times a day on the cellblock, in the cafeteria, outdoors, or when entering or exiting the visiting room. A prisoner may be forced to stand naked outside in a snowstorm, regardless of the danger of frostbite. This might happen below the gun tower, with M-16 or AR-15 rifles and shotguns pointed in the prisoner's direction.

Sometimes, in medium and maximum security prisons, when the COs thinks an inmate may have contraband hidden inside his or her rectum, a strip search will include a finger wave. Similar to a doctor conducting a prostate examination, the $\mathrm{CO}$ or medical professional (e.g., nurse) will insert a gloved finger in the rectum-but the correctional worker is much less likely to be as gentle as a doctor. It must also be remembered that staff do not necessarily have to inflict violence on an inmate themselves; they can often convince another prisoner to do it on their behalf (Cohen et al., 1976; Hemmens \& Atherton, 2000; Hemmens \& Stohr, 2001).

Sexual Relations With or Assault of Inmates ${ }^{7}$. Over the years, a long history of the sexual abuse of female convicts by male staff members at the women's prisons has been documented (Marquart et al., 2001; Worley, Marquart, \& Mullings, 2003). In most states, sexual relations or inappropriateness between prison staff and convicts is considered by law to constitute sexual assault or rape. Consensual sex between the keepers and the kept does not exist. Over the past two decades, hundreds of COs have been fired and/or indicted and convicted on sexual assault charges (Human Rights Watch, 1996; Moss, 2008; Stewart, 1998).

Some state prison systems, like Georgia's, have implemented tough "no touch, no contact" policies. In these situations, men are not allowed to supervise female convicts. If a male enters the unit, COs are instructed to announce "man [or male] on range." At some federal prisons for women, administrators have installed hotlines through which female prisoners can make complaints if they have been sexually abused. Sometimes this is a public relations exercise designed to garner support from the wider public by publicizing that something is being done about this problem. Nonetheless, several states have still not outlawed staff-inmate sex to date.

Although female sexual relations with inmates occurs (e.g., Worley, Tewksbury, \& Frantzen, 2010), historically sexual relations with prisoners have been more of a problem with male correctional employees than with female correctional workers (Beck, Harrision, \& Adams, 2007). However, news stories of male-on-male and female-on-female sexual relations are occasionally reported. For example, in 2000, Garrett Cunningham, while incarcerated at the Luther Unit of the 
Texas Department of Criminal Justice, was repeatedly raped, not by a fellow inmate but by a CO. Stories about female officers abusing male inmates are rare, as it is often perceived that male prisoners are the beneficiaries in this kind of behavior.

\section{Deviance Against Other COs}

Drinking on the Job. COs, who come to work under the influence of alcohol, drink on the job, use prescription, or over-the-counter drugs in a manner in which they are not prescribed, or illegal drugs that impair their judgment, are unable to properly respond to the demands of their work. They threaten not only their own safety but also that of their fellow COs. Alcohol use is often part of the CO subculture. Drinking is usually done for camaraderie, social bonding, and stress relief. Using illegal drugs, or using prescription drugs in a manner in which they were not intended, may set the CO up for charges of corruption (i.e., they are the first to be suspected of smuggling contraband into the facility), regardless of the means by which the substances were obtained.

General Boundary Violations. Boundary violations include "actions that blur, minimize, or disrupt the professional distance between correctional staff members and prisoners" (Marquart et al., 2001, p. 878). This type of conduct, includes inappropriate relationships, disregard the typical roles of COs as supervisors and guardians, and inmates as individuals who are to follow orders. This kind of deviance can be further demarcated into general boundary violations which are " "unserious' framebreaks committed by employees who accepted from inmates, or exchanged with inmates, ... drinks, food, craft work or materials, or wrote letters to prisoners" (Marquart et al., 2001, p. 883). Boundary violations upset the power relations between COs and the inmates.

Discrimination. Correctional workers and organizations, like most people, should be cognizant about discriminating based on age, race, ethnicity, sexual preference, and national origin. This kind of discrimination can occur in the hiring of potential COs and the treatment of inmates. Starting in the 1960s, a series of lawsuits were brought on behalf of women who applied to be COs. This coincided with massive changes due to the 1964 Civil Rights Act. These steps helped pave the way for the increased hiring and promotion of women in the corrections field (e.g., Zupan, 1992). Discrimination against women as COs does not simply end with hiring and promotion, but can be detected in "tokenism, differential treatment by male supervisors and administrators, and opposition by male co-workers" (Zupan, 1992, p. 330). Discrimination also takes on particularly ugly forms in the occasional news media story about COs being members of radical right-wing organizations, such as Aryan Nations or the Ku Klux Klan (Camp et al., 2001).

Sexual Harassment of Fellow Correctional Workers. Both male and female officers and administrators may engage in sexual harassment directed toward each other. This may include repeatedly asking fellow workers for dates, inappropriate touching, and stalking. Sexual harassment can also be exhibited in the creation of a hostile work environment by bringing pornographic magazines to work, displaying pornographic materials on the job, objectifying other individuals, and making comments about body parts (Belknap, 1995; Britton, 1997; Savicki, Cooley, \& Gjesvold, 2003; Stohr, Mays, Beck, \& Kelley, 1998; Worley \& Cheeseman, 2006).

Smuggling Contraband. Contraband is brought into prisons with the help of a variety of individuals, including COs (Kalinich, 1986; Lankenau, 2001). These items vary from institution to institution, from state to state, and typically include alcohol, cell phones, cigarettes, condoms, currency, drugs, nicotine patches, tobacco, and tattooing materials. These are often components of the "inmate economy" and are used for exchange. Correctional workers who bring in such items may have been 
compromised (e.g., an inmate or group of convicts may have damaging information on a CO that can be used against him or her), or they may see these opportunities as additional ways to supplement their income.

\section{Summary}

By far the most dominant acts of CO deviance are targeted against other officers. While on first pass, actions such as drinking on the job may put an officer at risk and damage the reputation of the institution, they primarily put other COs at risk.

\section{Types of Solutions to CO Deviance}

\section{Introduction}

There are at least 16 methods by which CO deviance can be minimized, curtailed, or controlled. These mechanisms are drawn from both the corrections and public administration literature. Solutions can be divided into three categories based on the point of implementation in the career /work pattern of a CO: preservice, in-service, and continuous.

Under the first category are included:

- conducting thorough background investigations on applicants;

- proper and thorough training; and

- certification.

The following actions fall within the second category:

- Participative Management/Total Quality Management (TQM);

- Using Power Appropriately;

- Reporting Malfunctioning or Broken Equipment in a timely manner;

- Exposing Waste and Violations of Rules; and

- The Use of Ombudsmen and Ethics Committees.

Under the last group of solutions we have:

- Realistic Alternatives to Selective Contraband and banned inmate behavior;

- Cultural Awareness-Diversity and Gender Sensitivity Training;

- Accreditation;

- Proper Employee Evaluation;

- Random Drug, Criminal Background, and Credit Checks;

- Better Leadership;

- The Creation and Use of Internal Affairs Units;

- Professionalism.

Before reviewing these mechanisms, however, it must be understood that the act of reporting deviance is not as simple as it may sound.

\section{Impediments to Reporting Deviance}

In principle, corruption, violence, or violations of rules should be reported. However, this is easier said than done. COs, like police officers, have to deal with the powerful effects of the occupational subculture, the so-called officer code (Kauffman, 1988), especially the "blue wall of silence," which 
means that coworkers will generally not reveal potentially harmful information about fellow correctional workers because this action may result in a lack of teamwork or mutual protection from inmates while on the job. Clearly, no CO relishes the thought of being in a dangerous situation and not being able to count on having backup. Thus, COs are very careful about reporting acts of deviance among their fellow officers. Officers that do reveal the wrongdoings of fellow COs, supervisors, or correctional facility administrators are often referred to as whistleblowers.

\section{Categories of Solutions}

\section{Preservice}

Conducting Thorough Background Investigations on Applicants. Before hiring a CO, most jurisdictions conduct a thorough examination of potential candidates. Most jails and prisons consider applicants who are U.S. citizens, between the ages of 18 and 37, who have completed high school or obtained its equivalent education (e.g., General Educational Diploma), have not had any felony convictions, and have had 2 years' work experience (www.bls.gov/oco/ocos156.htm). The Federal Bureau of Prisons (FBOP), in particular, wants its recruits to have either an undergraduate degree or 3 years' experience in a field delivering "counseling, assistance, or supervision to individuals." Applicants also must be in good health and meet the requirements of "physical fitness, eyesight, and hearing" (www.bls.gov/oco/ocos156.htm).

Typically, those wishing to work as a CO:

1. fill out an application with the relevant state or federal agency;

2. take a written test and a psychological examination (like the Minnesota Multiphasic Personality Inventory test or the California Personality Inventory), perform a physical test, and submit to a urine (i.e., drug) test;

3. submit to a criminal background investigation;

4. have a medical exam;

5. perform a physical ability/agility test;

6. have a face-to-face psychiatric test; and

7. have a personal interview (Freeman, 1999, Chapter 12).

This last step is often the most important, as seasoned human resource personnel are responsible for determining the suitability of potential candidates through face-to-face interviews.

Proper and Thorough Training. COs should be given proper training not only in the skills and knowledge of the job but also in the ethics, rules, and regulations of the position. Despite this objective, considerable differences with respect to how and where $\mathrm{CO}$ candidates are trained exist across the country. At a minimum, DOCs design their training based on "guidelines established by the ACA and the American Jails Association. Some States have regional training academies that are available to local agencies" (www.bls.gov/oco/ocos156.htm). Initial training may occur at a formal state-run academy with the balance of knowledge, skills, and training being delivered at an actual correctional facility. At the academy or at the correctional facility to which they are assigned, $\mathrm{CO}$ candidates receive instruction in self-defense, firearms, "institutional policies, legal regulations, and operations, as well as custody and security procedures" (www.bls.gov/oco/ocos156.htm). Increasingly courses on integrity and ethics are being taught to rookies (Stewart, 1998, p. 83). While on the job, recruits typically serve out a probationary period and are subject to random drug testing. "Officer trainees typically receive several weeks or months of training in an actual job setting under the supervision of an experienced officer" (www.bls.gov/oco/ocos156.htm). In the FBOP, recruits "must undergo 200 hours of formal training within the first year of employment. They also must 
complete 120 hours of specialized training at the U.S. Federal Bureau of Prisons residential training center at Glynco, GA, within 60 days of their appointment" (www.bls.gov/oco/ocos156.htm).

The training process is typically expensive for the state and federal correctional systems. Thus, they try to weed out unsuitable candidates early in the process to prevent the expenditure of additional hiring costs (Conover, 2001). Unlike most police departments, some correctional agencies require their new hires to start immediately on the job; after a probationary period of working on a tier or cellblock, the new employees are then sent to the training academy. This alternate course was developed when various DOCs were placed in awkward positions after authorizing the costly training of new recruits only to have the new hires quit after experiencing the monotony and fear attendant to their jobs. Most DOCs separate recruits into different groups and provide them with specialized training, before moving on to the next group of new hires. This approach relies on the understanding that the majority of the new employees will learn the bulk of their responsibilities through experience and not in a classroom setting. The administration hopes "that recruits will learn general job responsibilities, procedures for carrying out these responsibilities, practical skills for task performance, and something about the expectations of supervisors" (Champion, 2005, p. 488).

Certification. The certification of COs, including requiring them to learn a specific body of knowledge, to adhere to certain moral and ethical standards, and to undergo periodic testing for certification renewal, may decrease the possibility of deviance (Levinson, Stinchcomb, \& Greene, 2001). A small number of membership organizations (e.g., ACA) have recently started to certify COs. Among other options, individual states could develop certification processes and have COs receive licensure through designated certification entities, such as the ACA or a state regulatory agency. The national prison commission made the following suggestion:

Treat criminal justice professionals just like doctors and lawyers, by making their employment conditional upon a valid license or certification. Half of the states in the country, however, lack a formal process for certifying qualified corrections officers and decertifying those who violate the law or rules of professional conduct. Additionally, there is no national-level mechanism that exists to record and share such information among local jurisdictions and states. Thus, dangerous officers can find employment in different facilities and systems because their past behavior is not known to new employers. (Gibbons \& Katzenbach, 2008, p. 71-72)

The commission also recommended the creation of a national $\mathrm{CO}$ data bank to prevent the ongoing employment of trouble officers.

\section{In-Service}

Participative Management/TQM. During the 1980s and 1990s, correctional facilities, inspired by the private sector, introduced new opportunities for line staff to contribute to the formation of institutional policies and practices. This process called TQM has been evaluated through an array of select experiments. Most evaluations suggested that TQM existed in name only and that it had to compete with an older paramilitary approach to managing correctional personnel. TQM is often no more than a buzzword used to describe techniques that are intended to encourage employees to become more involved the in decision-making process. When it is properly utilized, TQM is not simply window dressing (Freeman, 1999, Chapter 11). To the contrary, it can actually help the corrections system to act on the input of workers (Slate \& Vogel, 1997; Slate, Vogel \& Johnson, 2001; Stinchcomb, 1998).

Using Power Appropriately. The general public may presume that correctional facilities, administrators, and officers are, by nature, authoritarian (Freeman, 1999, Chapter 9). This impression, 
influenced by the mass media depictions of COs, derives from the numerous rules that inmates must follow and from the fact that infractions typically lead to some sort of administrative action or even physical action on the part of the COs. The stereotypes about officer authoritarianism do not mirror reality. COs do not have the resources to sanction each inmate. They recognize that, in general, they are outnumbered and that forcing convicts to do things against their will most likely backfire.

In order to accomplish their jobs, COs must make appropriate use of their power. Hepburn (1985) categorized five kinds of power: legitimate, coercive, reward, expert, and referent. The most useful types are legitimate and expert power; the worst type is coercive. By law, COs are empowered to do certain things. They know the policies and procedures of their institutions better than anyone else and can help guide inmates through their daily routines. In terms of expertise, COs should know the institutional rules better than the prisoners; this creates a context in which each CO can work effectively. Hepburn concluded that effective COs inspire prisoners' cooperation through a complicated set of rewards and punishments. Some of the privileges include periodically ignoring the rules, overlooking violations, granting choice job assignments, and writing favorable reports. The problem with this kind of exchange relationship is that it has the potential of being taken to the extreme. For example, a CO may smuggle in contraband or encourage illegal behavior on the part of the convicts.

Reporting Malfunctioning or Broken Equipment in a Timely Manner. In order to minimize the likelihood of being blamed for malfunctioning or broken equipment and to insure inmate and personal safety, COs should inform the proper individuals in their correctional institutions in a timely fashion about equipment issues. Timeliness is especially important if the problems are tied to safety-related equipment. If the administration is slow to fix or replace broken equipment, then correctional workers can often file a report through a union representative (e.g., shop steward). Such reluctance to deal with broken equipment can spark cynicism about the organization at large.

Exposing Waste and Violations of Rules. Although the "blue wall of silence" among correctional workers is ever present, most training manuals advise recruits to report infractions to their immediate supervisors. This is easier said than done because of the ramifications a correctional worker might experience if he or she reports coworker infractions. When considered from various perspectives, there are rational-sounding arguments for both reporting violations and remaining silent. It is relatively painless for outsiders to take the moral high ground and to cite the whistleblower legislation that currently exists in some states and at the federal level. However, one should consider the complications that arise when the deviant individual in question is a CO's immediate supervisor or when the reporting $\mathrm{CO}$ has previous acts of misconduct that he or she wants to hide or remain hidden.

Most COs are naturally timid about reporting the deviance of coworkers. Those who choose to remain silent often do so out of fear of retaliation from fellow officers and administrators. Once COs consider a colleague to be a snitch, that individual may find himself or herself without the necessary support in dangerous situations. One major deciding factor comes into play when COs anticipate that not reporting their colleagues' deviant behavior may later wind up implicating themselves; in such a case, a CO may feel a stronger obligation to inform appropriate-level superiors of an infraction. From a strictly moral or ethical point of view, the failure to report an act of deviance can be almost as bad as committing the act in the first place. Most DOCs stress that employees have a duty to report infractions. Some ways are better than others for the reporting of violations of norms, policies, and practices. Face-to-face or confrontational situations are not always the best means and methods of communication. The more experience COs have, the greater the odds will be that they will discover and utilize ways to report wrongdoings so that they will not be caught in an undesirable situation in the future. Sometimes, this may mean talking to the offending person in private. On the flip side, 
once the deviant behavior has been reported, management may attempts to blame the incident (i.e., pass the buck) on the workers and to deny responsibility for its failure to manage or lead.

The Use of Ombudsmen and Ethics Committees. Occasionally, correctional facilities or DOCs have ombudsmen who on their own or with their staff investigate abuse and cut through the red tape for prisoners, their loved ones, and correctional workers. An additional mechanism to serve as a check on correctional work is the use of ethics committees, which consist of groups of "every level of management, union representatives, and community representatives" that review complaints against COs (Freeman, 1999, p. 354). A similar function is conducted by an inspector general who acts as in-house quality control in large government organizations.

\section{Continuous (i.e., Starts in Preservice and Continues During In-Service)}

Realistic Alternatives to Selective Contraband and Banned Inmate Behavior. Many problems connected with the banning of some contraband items (e.g., tobacco, nicotine patches, and cell phones) can be solved though alternative policies and practices then what currently exist. Correctional facilities are not health institutions, thus the complete elimination of the possession and use of tobacco is in many respects overzealous. Thus, having designated places where smoking is allowed (e.g., in the yard) may be preferable to a complete ban on tobacco-related products. Likewise, abnormally the high-financial costs incurred by inmates associated with telephone use, including strict rules on access, may in fact contribute to the increased smuggling of cell phones into prisons. Likewise the numerous incidents of inappropriate contact between inmates and COs, sometimes initiated by inmates for one reason or another, might be lessened if the ability and practice of conjugal visits is liberalized.

Cultural Awareness-Diversity and Gender Sensitivity Training. In order to minimize acts of discrimination against inmates and fellow officers, many correctional institutions require employees to take cultural diversity and gender sensitivity training. This is often carried out by an employee of a state DOC who makes the rounds of each individual correctional facility. Sometimes the instructor provides lectures on relevant topics, while at other times, he or she may use group activities (e.g., scenario development) in order to teach COs the implications of their actions and to present various methods for diffusing work place problems (Freeman, 1999, p. 67).

Accreditation. In order to improve the working conditions at a prison, correctional managers and officials can seek accreditation by the ACA, which has developed standards that have been agreed upon by recognized experts. Accreditation helps ensure that an organization remains current and functions to the best of its ability. The accreditation process requires prisons to submit to voluntarily inspections by the ACA, representatives of the media, scholars, and possibly, a board appointed by a governor; this is a complex relationship, but it typically leads to improvements in a facility's programs and infrastructure. COs commonly do not like working in institutions that have practices, rules, and regulations that do not appear to make sense. These protocols may have seemed logical to previous administrations, but they may appear inappropriate, silly, or antiquated in comparison to current practices and conditions.

Proper Employee Evaluation. Most correctional facilities assess their employees' performance. These evaluations provide many benefits, including preventing COs from engaging in deviance or crime and providing discipline for employees who have engaged in periodic deviance. Performance evaluations can be as simple as a written report, in which a supervisor checks off items on a list, or as complicated as a process of negotiation between a boss and an employee. Performance appraisals 
are also mediated by union regulations and are often tied to bonuses and pay raises (Latham \& Wexley, 1981).

Random Drug, Criminal Background, and Credit Checks. Since the dawn of urine tests, criminal background, and credit checks as a condition for screening applicants for employment, an increasing number of professions use this practice as method to protect the integrity of their employees and their institutions. The field of corrections is no different. Not only should COs be subject to random post hiring drug testing, but in order to be employees in good standing COs should be subject to periodic criminal and credit checks. This kind of evaluation serves as a deterrent for COs that may engage in various questionable behaviors. Simultaneously, correctional facilities should provide free (psychological and financial) counseling, and be willing to provide referrals to well-qualified professionals and agencies in the community that can offer treatment/assistance for employees who need it. In addition to random drug, criminal background, and credit checks, correctional institutions would be best served if, as in many jurisdictions, close cross-gender supervision was eliminated. A reduction in corruption, violence, and inappropriate relationships (including ones of a sexual nature), might be achieved if the number of strategically placed video cameras that exist in facilities was increased. Although one might argue that both inmates and COs will find spaces where closed circuit television is not present, this practice will serve as a deterrent.

Better Leadership. Better leadership is critical to the minimization of deviant behavior among COs. Not only is it necessary for managers and wardens to have the appropriate qualifications for their leadership positions (such as, relevent experience and education), but they must evaluate situations from a broad perspective and should not be authoritarian. Administrators must be able to motivate a team. They also need to be proactive and not simply reactive. "Effective correctional leadership involves a set of practices that acknowledges both the internal and external environment of corrections" (Freeman, 1999, pp. 236-237). One must keep in mind that a distinction exists between managers and leaders. Managers usually help workers perform their daily tasks, including processing the appropriate paperwork, whereas leaders see the bigger picture and plan for the organizational mission. The correctional field needs administrators who are not simply managers but who are leaders who help their organizations move forward and deal with both planned and unanticipated changes (Riveland, 1997; Stojkovic \& Farkas, 2003).

The Creation and Use of Internal Affairs Units. Most DOCs have developed mechanisms to investigate allegations of officer or administrator wrongdoing. The relevant oversight is provided by entities that go by a variety of names, including offices of inspector generals, offices of professional responsibility, and departments of internal affairs. Once a complaint is launched, these offices usually collect evidence that substantiates the complaint or exonerates the accused. In some DOCs, if evidence of wrongdoing is found, an office will take this information to the institution's warden or to the state's commissioner or secretary of corrections for further action (i.e., dismissal, sanction, etc). In various jurisdictions, the internal affairs authorities have the power to arrest the accused officer (Bell, 2002; Freeman, 1999, pp. 356-357).

Sanctions. Depending on the severity of the deviance, an internal investigation may be opened, and typically the $\mathrm{CO}$ in question will appear in front of an in-house disciplinary board. This unit can recommend dismissal, transfer, docking of pay, or retraining. If the matter is of a criminal nature, then formal criminal charges can be made through the local district attorney. In such an instance, the officer is typically allowed to be represented by a lawyer or a representative of his or her correctional union. The message from such proceedings is that the administration is not satisfied with business as usual. 
Professionalism. Closely connected to the issue of training is that of professionalism. Over the past 80 years, corrections, much like the fields of law and medicine, has adopted rigorous standards for the training and certification of its workers. This change is largely a reflection of the recognition that in order for COs to do their job properly, they need specialized knowledge, skills, and training. Instructional topics may include conducting searches, controlling and restraining convicts, writing and speaking effectively, providing proper medical and emergency care, transporting prisoners, selfdefense, and using a variety of weapons (e.g., firearms and chemical weapons). Many of these policies and practices are contained in standards which are specified by state DOCs and by national accrediting bodies like the ACA (Farkas, 1990; Stinchcomb, 2000).

Not all solutions are as important as others. Methods to reduce CO deviance require resources. Cash-strapped correctional facilities and DOCs must make cost-benefit decisions regarding where they want to invest to prevent and properly respond to $\mathrm{CO}$ deviance. In general, and historically proactive measures (i.e., those that are taken before the individual becomes a sworn officer) are believed to be better for the correctional system as a whole. But DOCs must also implement processes and safeguards that are universally agreed upon to be useful throughout the COs employment in the field. It is expensive recruiting and training COs, and instead of weeding out the COs who engage in deviance on the job, it may be in the best interest of the institution to have procedures in place to reinforce their employees' commitment to integrity. In this case, accrediting bodies and $\mathrm{CO}$ unions can been useful in monitoring and insuring that COs commit to professionalism.

\section{Conclusion}

COs' deviance leads to a breakdown in inmate-officer and officer-officer trust. This perception has a wide audience and may contribute to a decrease in public confidence in correctional facilities' ability to do their jobs (e.g., Mancini \& Mears, 2013). When this trust is lost, it is rarely reasserted, and when it is, an incredible amount of time is required to reestablish it. If levels of deviance are high, a facility cannot work at an optimal level and cannot successfully implement meaningful rehabilitative programs. Both COs and managers must be conscientious in their efforts to prevent themselves from participating in deviant behavior and to insure that they deal with incidents in a timely fashion.

In order to build upon this research, it might be interesting to examine how COs, other correctional workers, correctional administrators, convicts, and ex-convicts feel about the seriousness of not only the types of deviance described in this article, but also the solutions suggested here. ${ }^{8}$ In this case, perhaps an exploratory study administered to each of these groups of individuals might highlight similarities and differences among these diverse groups and point the way to solutions that are realistic. In short, this framework should serve as the basis for further theory building and possible model development.

\section{Acknowledgments}

The author would like to thank the editor and the anonymous reviewers for their helpful comments on the previous version of this article. Special thanks to Nancy Hogan, Eric Lambert, and Rachel Hildebrant for comments.

\section{Declaration of Conflicting Interests}

The author declared no conflicts of interest with respect to the research, authorship, and/or publication of this article.

\section{Funding}

The author received no financial support for the research, authorship, and/or publication of this article. 


\section{Notes}

1. Although this analysis is mainly tailored toward prisons and correctional officers who work in them, many of the actions that are identified occur in jail settings too.

2. There are some exceptions to this observation. Freeman (1999) and Phillips and McConnell (2005), who have written prison administration texts, have separate chapters which look at the problem of ethics in correctional settings. Likewise, there has been some fledgling work done on correctional ethics at every level of the penitentiary (e.g., Kleining \& Smith, 2001).

3. Research on prison administrators and probation and parole officers is relevant, however this review is restricted to the work that explicitly focuses on correctional officers.

4. Thus, this review ignores prisoner and prison activist initiated solutions. For a review of prisoner resistance, see, for example, (Ross, 2010).

5. Although it has been suggested that in order to proceed, it might be helpful to either derive these controls from the scholarly literature on deviance by law enforcement officers, or compare them with police officer, however, the author argues that although both work in the criminal justice system, there are significant contextual differences mitigating this approach.

6. This is based on a review of scholarly research, news media reports, informal conversations with both inmates and correctional workers, and informed by the writers' 4 years of work inside a correctional facility. Where appropriate the author attempted to cite scholarly sources.

7. A closely related act of deviance is having sexual relations with the wife, husband, boyfriend, or girlfriend of the inmate.

8. See, for example, Stohr, Hemmens, Kifer, and Schoeler (2000) and Worley and Worley (2011) for an example of this type of research.

\section{References}

Abbey, E. (1975). The monkey wrench gang. New York, NY: Harper.

Adler, P. (2005). Constructions of deviance. Belmont, CA: Wadsworth.

Barker, T., \& Carter, D. L. (1994). Police deviance (3rd ed.). Cincinnati, OH: Anderson.

Beck, A. J., Harrison, P. M., \& Adams, D. B. (2007). Sexual violence reported by correctional authorities, 2006 (NCJ218914). Washington, DC: Bureau of Justice Statistics.

Belknap, J. (1995). Women in conflict: An analysis of women correctional officers. In B. R. Price \& N. J. Sokoloff (Eds.), The criminal justice system and women: Offenders, victims and workers (2nd ed., pp. 195-227). New York, NY: McGraw-Hill.

Bell, W. R. (2002). Practical criminal investigations in correctional facilities. Boca Raton, FL: CRC Press.

Bowker, L. H. (1980). Prison victimization. New York, NY: Elsevier Science.

Britton, D. (1997). Perceptions of the work environment among correctional officers: Do race and sex matter? Criminology, 35, 85-105.

Camp, S. D., Saylor, W. G., \& Wright, K. N. (2001). Racial diversity of correctional workers and inmates: Organizational commitment, teamwork and workers' efficiency in prisons. Justice Quarterly, 18, 411-427.

Champion, D. J. (2005). Corrections in the United States: Contemporary perspectives (4th ed.). Upper Saddle River, NJ: Prentice Hall.

Clemmer, D. (1958). The prison community. New York, NY: Holt, Rinehart.

Cohen, A. K., Cole, G. F., \& Bailey, R. G. (1976). Prison violence. Lexington, MA: Lexington Books.

Conover, T. (2001). Newjack: Guarding Sing Sing. New York, NY: Vintage Books.

Farkas, M. A. (1990). Professionalization: Is it the cure-all for what 'ails' the corrections officer. Journal of Crime and Justice, 13, 29-54.

Freeman, R. (1999). Correctional organization and management. Woburn, MA: Butterworth-Heinemann.

Gibbons, J. J., \& de B. Katzenbach, N. (2008). Confronting confinement: A report of the national commission on safety and abuse in prison, 2006. Retrieved from www.prisoncommission.org 
Hemmens, C., \& Atherton, E. (2000). Use of force: Current practice and policy. Lanham, MD: American Correctional Association.

Hemmens, C., \& Stohr, M. K. (2001). Correctional staff attitudes regarding the use of force in corrections. Corrections Management Quarterly, 5, 26-39.

Hepburn, J. (1985). The exercise of power in coercive organizations: A study of prison guards. Criminology, 23, $145-164$.

Hersh, S. M. (2004). Chain of command: The road from 9/11 to Abu Ghraib. New York, NY: HarperCollins. Human Rights Watch. (1996). All too familiar: Sexual abuse of women in U.S. prisons. New York, NY: Author. Human Rights Watch. (2001). No escape: Male rape in U.S. prisons. New York, NY: Author.

Irwin, J. (1970). The felon. Englewood Cliffs, NJ: Prentice Hall.

Irwin, J., \& Cressey, D. R. (1962). Thieves, convicts and the inmate culture. Social Problems, 10, 142-155.

Kalinich, D. B. (1986). Power, stability, and contraband: The inmate economy. Prospect Heights, IL: Waveland.

Kappeler, V. E., Sluder, R. D., \& Alpert, G. P. (1998). Forces of deviance: Understanding the dark side of policing (2nd ed.). Prospect Heights, IL: Waveland Press.

Kauffman, K. (1988). Prison officers and their world. Cambridge, MA: Harvard University Press.

Kerness, B., \& Ehehosi, M. (2001). Torture in U.S. prisons: Evidence of U.S. human rights violations. Philadelphia, PA: American Friends Service Committee.

Kleining J. \& Leland Smith M. (Eds.) (2001). Discretion, community and correctional ethics. Lanham, MD: Rowman and Littlefield.

Lankenau, S. E. (2001). Smoke 'em if you got 'em; Cigarette black markets in US prisons and jails. Prison Journal, 81, 142-161.

Latham, G. P., \& Wexley, K. N. (1981). Increasing productivity through performance appraisal. Menlo Park, CA: Addison-Wesley.

Levinson, R. B., Stinchcomb, J. B., \& Greene, III, J. J. (2001). Correctional certification: First step toward professionalization. Corrections Today, 63, 125-138.

Mancini, C. \& Mears, D. P. (2013). The Effects of agency scandal on public views toward the correctional system, Criminal Justice Review, 38, 5-28

Marquart, J. W. (1986). Prison guards and the use of physical coercion as a mechanism of prisoner control. Criminology, 24, 347-366.

Marquart, J. W., Barnhil, M. B., \& Balshaw-Biddle, K. (2001). Fatal attraction: An analysis of employee boundary violations in a southern prison system 1995-1998. Justice Quarterly, 18, 877-910.

McCarthy, B. J., Jr. (1996). Keeping and eye on the keeper: Prison corruption and its control. In M. C. Braswell, B. R. McCarthy, \& B. J. McCarthy (Eds.), Justice, crime and ethics (2nd ed., pp. 229-241). Cincinnati, $\mathrm{OH}$ : Anderson.

Morrow, C. K. (1982). Sick doctors: The social construction of professional deviance. Social Problems, 30, 92-108.

Moss, A. (2008). Sexual misconduct. In P. M. Carlson \& J. S. Garrett (Eds.), Prison and jail administration (2nd ed., pp. 275-289). Boston, MA: Jones and Bartlett.

Phillips, R. L., \& McConnell, C. M. (2005). The effective corrections manager: Correctional supervision for the future (2nd ed.). Sudbury, MA: Jones and Bartlett.

Pratt, T. C., Maahs, J., \& Hemmens, C. (1999). The history of the use of force in corrections. In C. Hemmens \& E. Atherton (Eds.), Use of force: Current practice and policy (pp. 13-22). Lanham, MD: American Correctional Association.

Riveland, C. (1997). The correctional leader and public policy skills. Corrections Management Quarterly, 1, $22-25$.

Ross, J. I. (2010). Resisting the Carceral state: Prisoner resistance from the bottom up. Social Justice, 36, $28-45$.

Ross, J. I., \& Richards, S. C. (2002). Behind bars: Surviving prison. Indianapolis, IN: Alpha Books. 
Ruggerio, M., Greenberger, E., \& Steinberg, L. D. (1982). Occupational deviance among youth workers. Youth and Society, 13, 423-448.

Savicki, V., Cooley, E., \& Gjesvold, J. (2003). Harassment as a predictor of job burnout in correctional officers. Criminal Justice and Behavior, 30, 602-619.

Slate, R., \& Vogel, R. E. (1997). Participative management and correctional personnel: A study of the perceived atmosphere for participation in correctional decisions making and its impact on employees stress and thoughts about quitting. Journal of Criminal Justice, 25, 397-408.

Slate, R. N., Vogel, R. E., \& Johnson, W. W. (2001). To quit or not to quit: Perceptions of participation in correctional decision making and the impact of organizational stress. Corrections Management Quarterly, $5,68-78$.

Souryal, S. (2009). Deterring corruption by prison personnel: A principle-based perspective. Prison Journal, $89,21-45$.

Stewart, C. H. (1998). Management response to sexual misconduct between staff and inmates. Corrections Management Quarterly, 2, 81-88.

Stichman, A. J. (2002). The sources and impact of inmate perceptions of correctional officers' bases of power (PhD dissertation). Cincinnati, OH: University of Cincinnati.

Stinchcomb, J. B. (1998). Quality management in corrections implementation issues and potential policy implications. Criminal Justice Policy Review, 9, 123-136.

Stinchcomb, J. B. (2000). Developing correctional officer professionalism: A work in progress. Corrections Compendium, 25, 1-4, 18-19.

Stohr, M. K., Hemmens, C., Kifer, M., \& Schoeler, M. (2000). We know it, We just have to do it: Perceptions of work in prisons and jails. Prison Journal, 80, 126-150.

Stohr, M. K., Mays, G. L., Beck, A., \& Kelley, T. (1998). Sexual harassment in women's jails. Journal of Contemporary Criminal Justice, 14, 135-155.

Stojkovic, S. (1984). Social bases of power and control mechanisms among prisoners in a prison organization. Justice Quarterly, 1, 511-528.

Stojkovic, S., \& Farkas, M. A. (2003). Correctional leadership: A cultural perspective. Belmont, CA: Wadsworth.

Sykes, G. (1958). The society of captives. Princeton, NJ: Princeton University Press.

Worley, R. M., \& Cheeseman, K. A. (2006). Guards as embezzlers: The consequences of 'nonshareable problems' in prison settings. Deviant Behavior, 27, 203-222.

Worley, R. M., Tewksbury, R., \& Frantzen, D. (2010). Preventing fatal attractions: Lessons learned from inmate boundary violators in a southern penitentiary system. Criminal Justice Studies, 23, 347-360.

Worley, R. M., \& Worley, V. B. (2011). Guards gone wild: A self-report study of correctional officer misconduct and the effect on institutional deviance on 'care' within the Texas prison system. Deviant Behavior, 32, 293-319.

Worley, R. M., \& Worley, V. B. (2013). Games guards play: A self-report study of institutional deviance within the Texas department of criminal justice. Criminal Justice Studies: A Critical Journal of Crime, Law and Society, 26, 115-132.

Zupan, L. (1992). The progress of women correctional officers in all-male prisons. In I. L. Moyers (Ed.), The changing role of women in the criminal justice system (2nd ed., pp. 232-244). Prospect Heights, IL: Waveland Press.

\section{Author Biography}

Jeffrey Ian Ross, PhD, is a professor in the School of Criminal Justice at the University of Baltimore and a fellow in the law school's Center for Comparative and International Law. 